Building Global Labor Solidarity that, I suggest, one must turn to appreciate the import of and the challenges that arise in building global labour solidarity.

Stuart Rosewarne

The University of Sydney

\title{
James Kirby, Historians and the Church of England: Religion and Historical Scholarship, 1870-1920 (Oxford: Oxford University Press, 2016). 257pp. Hardcover \$100.00.
}

Historians now take seriously historical scholarship's polemical potential for the Church of England's proponents and opponents. Peter Lake, Anthony Milton, Justin Champion, Jean-Louis Quantin, Rob Iliffe, and Brian Young have written particularly fine studies for the early modern period. They have shown that while early modern historians of religion deployed evidence in increasingly sophisticated ways, historical erudition got deployed for inherently polemical ends. It is not, though, as if nineteenth-century historians have missed that their own era's historians produced scholarly, yet polemical, histories of the English Church. So, the first thing that James Kirby had to do in his admirable Historians of the Church of England: Religion and Historical Scholarship, 1870-1920, was to explain what differentiates his study from those of Duncan Forbes, John Burrow, Christopher Parker, Michael Bentley, and others. Kirby reckons that earlier work on nineteenth-century religious histories has mostly been insufficiently contextualized intellectual history; his book, though, aims "to contribute not only to the history of ideas (religious and historiographical), but also the histories of scholarship, universities, and the Church of England as an institution" (9).

Historians of the Church of England focuses on the histories produced by late Victorian Anglicans about the English Church. While acknowledging that Nonconformists, Roman Catholics, and a host of other non-Anglicans wrote polemical religious histories between 1870 and 1920, Kirby keeps his sights on Anglican historians and on intra-Anglican historical debate. In the process, he tries to explain why, who, how, where, and what religious history got produced by Anglicans during the late nineteenth and early twentieth centuries. The reason why late nineteenth-century Anglicans produced historical scholarship is clear: well into the next century, history remained the primary site of religious debate. It is a commonplace that Anglicans value history, since reason, faith, and tradition are held to be the three-legged stool atop which Anglicanism rests. Historical scholarship is a way to ascertain and understand that putative Anglican tradition; historical scholarship might even create Anglican tradition. Three other things gave the past salience for the late nineteenth-century Anglican present. Firstly, the Reformation was, among other things, an attempt to restore the English Church 
to its primitive purity: historical scholarship was central to that restoration project, since it might identity what had been primitive orthopraxis and orthodoxy and might, furthermore, pinpoint when the primitive Church had been corrupted. Secondly, recognition that the thing we now call the English Enlightenment was not a rationalist, metaphysical movement, but was instead a long debate about the past's hold on the present: England's Enlightenment was a historiographical moment. Thirdly, there was the Oxford Movement. As Kirby puts it, "[t]he decisive force behind the ascent of Anglican historical scholarship in the later Victorian period was the Oxford Movement, or Tractarianism” (20). In making this judgment he builds on Peter Nockles's work and rightly breaks from the earlier estimates of Forbes and Burrow; at the very least, it may be said that none of the historians who populate Kirby's book were neutrals regarding the Oxford Movement. Late nineteenth-century Anglican historians of the Church of England, then, inherited the Reformation, the Enlightenment, and the Tractarian preoccupations with history; and in the half-century after 1870 they traversed much the same ground that their Anglican historian forbears had done. On Kirby's telling, though, issues of orthopraxis and orthodoxy mattered less to Anglican historians between 1870 and 1920 than did "the confessional defence of the Church of England's position in Christendom; and the constitutional defence of the Church of England's rights in the English polity" (9). For the established Church of England operating in a world after the repeal of the Test and Corporation Acts, after Catholic emancipation, and during the rapid expansion of Britain's empire, those inter-confessional and constitutional issues were not of secondary importance.

History, then, mattered to the Church of England and that, in turn, fueled what Kirby identifies as a central feature of Anglican identity_ " "the idea of the learned church." The Anglican historians who engaged with the confessional and constitutional issues he identifies drew mainly from the High and Broad Church traditions, with figures like William Stubbs, E.A. Freeman, and Mandell Creighton hailing from the former camp and those like J.R. Green, J.R. Seeley, and T.F. Tout hailing from the latter. Interestingly, Kirby identifies few Evangelical Anglican historians, whose dearth he chalks up mainly to the fact that Evangelicals were largely uninterested in post-biblical evidence and that they were "less committed to scholarship as such, prioritizing proselytism and the understanding of basic doctrines over the accrual of erudition, which they feared might lead to pride" (39). Those Anglicans who did write histories of the English Church did not just live within the golden triangle bounded by Oxford, Cambridge, and London. Some wrote from local parishes, some wrote from cathedral communities, some wrote from the universities - not just Oxford and Cambridge but also King's College, London, and Owens College, Manchester-and some, like Stubbs and Creighton, wrote from all three.

The bulk of Kirby's book covers what these historians actually wrote. Deliberately avoiding studies of Christian antiquity, Kirby instead focuses on his- 
tories of the post-primitive Church. In five thematic chapters, he examines what late Victorian Anglican historians had to say about the nation, the constitution, social and economic history, the Reformation, and providence and progress. Predictably, there was no scholarly consensus on any of these issues, and Kirby ably schematizes potentially unruly material, identifies the points of contention, and illustrates how and why historians marshalled different bodies of evidence to reach different conclusions. While each of the five thematic chapters can be read as a stand-alone piece, a few salient themes run across them. Most importantly, they reveal that late Victorian Anglican historians of the English Church, like their Anglican historian predecessors, obsessed about what had led to the cataclysm of the 1530s and what had happened afterwards.

The Reformation settlement is the subject of one chapter, but the Reformation's causes, course, and consequences are persistent subjects across the book. Why had the Christian church splintered into national churches? Was the English Church's primary inheritance English or British? How had the English Church related to the Roman one before the 1530s? When had the Reformation really happened: under Henry VIII, Edward VI, or Elizabeth I? And what did the reign of Mary Tudor mean? Was the Reformation a break with English religious history, or not? Had it cemented or created the Erastian English state? Or, was England's Erastianism illusory? What were the economic and constitutional effects of dissolving the monasteries? Had English Protestantism created capitalism? These and a host of other questions like them run across the chapters giving a deep coherence to Kirby's book. If the late Victorian historians who are the subject of the book could not agree on the answers to these questions, at least they could agree that these were the questions to be asking. Historians of the Church of England ends, though, pointing towards a future when there were fewer polemical Anglican historians who took up these questions. Yes, there were Anglican historians who wrote about the Anglican pasts, but, on Kirby's telling, they did so with less confidence or openness than their late Victorian forbears had done. Whether or not this was the case is debatable, but it will take a historian of James Kirby's industry and insight to illuminate the polemical ends of Anglican historians from Claude Jenkins and Norman Sykes to Gareth Bennett and Patrick Collinson.

Robert G. Ingram Ohio University 